\title{
Ефективність збагаченої тромбоцитами плазми крові в індукції загоення м'язової тканини в експериментальному дослідженні
}

\begin{abstract}
Мета роботи: вивчити в експерименті вплив збагаченої тромбоцитами плазми крові в індукції загоєння м’язової тканини після травматичного ураження.

Матеріали і методи. Експеримент проведено на 92 лабораторних щурах, які знаходились на стандартному раціоні віварію. Дослідні тварини були розділені на три групи: контроль - 12 інтактні, перша дослідна група - 40 із травматичним ураженням м'язів стегна без введення збагаченої тромбоцитами плазми крові, друга дослідна група - 40 з травматичним ураженням м'язів стегна та введенням збагаченої тромбоцитами плазми крові. Приготування PRP відбувалося двохетапно. Було проаналізовано вплив корекції збагаченої тромбоцитами плазми крові на зміни пероксидного окиснення ліпідів (ПОЛ) та антиоксидантного захисту (AOC) і морфологічні зміни в м’язовій тканині в експерименті при травматичному ураженні м’язів, яким проводилася корекція збагаченою тромбоцитами плазмою крові. Забір біологічного матеріалу проводили на 1-шу, 7-му, 14-ту, 21-шу доби після травматичного ураження м’язів.

Результати досліджень та їх обговорення. Встановлено, що застосування збагаченої тромбоцитами плазми крові призводить до зменшення активності пероксидного окиснення ліпідів, що зумовлює зменшення ознак запалення в травмованому м'язі, які морфологічно проявляються на 7-му, 14-ту добу, 21-шу доби наступними змінами: на 7-му добу ділянка пошкодження була представлена помірними дистрофічними змінами в м'язових волокнах, незначним набряком та збільшенням кількості фібробластів. Через 14 діб візуалізувалась незначна кількість колагенової строми із сформованою грануляційною тканиною, залишкові явища набряку та поодинокі дистрофічні зміни м’язів, некротичні прояви не спостерігались. На 21-шу добу в ділянці пошкодження пухкі колагенові волокна заміщувались гіалінізованою стромою. Різко зменшувалась кількість лімфо- та плазмоцитів, фібробластів, опасистих клітин та практично зникав периваскулярний набряк. Чітко збереженими візуалізувались судини мікроциркуляторного русла. Покращувалась структура самих м’язових волокон: саркоплазма інтенсивніше сприймала барвники, ядра відновлювали свою локалізацію.
\end{abstract}

Ключові слова: травма м’язів; збагачена тромбоцитами плазма крові; PRP; пероксидне окинення ліпідів; антиоксидантна система.

Постановка проблеми та аналіз останніх досліджень та публікацій. Пошкодження м'яких тканин є найбільш розповсюдженими наслідками травм органів опорно-рухового апарату [1]. Незважаючи на численні дослідження рівень травматизму та смертності залишається значним. Так, за прогнозами ВООЗ, травми внаслідок дорожньо-транспортних пригод будуть провідною причиною смерті до 2030 року. В різних країнах світу травми в спорті становлять близько 10 - 20 \% від пошкоджень. У спортсменів ігрових видів спорту найчастіше мають місце травматичне ураження м’язів [2, 3].

Основним механізмом пошкодження при травматичному ураженні $є$ генерація активних форм кисню, які активують пероксидне окиснення ліпідів (ПОЛ). Враховуючи недостатність системи антиоксидантного захисту (АОС) відбувається системне пошкодження клітинних мембран внаслідок пероксидації їх ліпідного шару. Травматичне ураження м’язової тканини знижує життєздатність клітин в місці ураження, що підтверджується морфологічними змінами [4].

Оксидативний стрес, що розвивається при травмах, супроводжується гіперпродукуванням вільних радикалів на фоні виснаження ендогенних антиоксидантних резервів [5]. Також при травмі експериментальні та клінічні дані свідчать про те, що тромбоцити визначають як відповідні модулятори інших фізіопатологічних процесів, включно запалення та регенерацію тканин. Ці явища опосередковуються за рахунок вивільнення факторів росту, цитокінів і позаклітинних матрицевих модуляторів, які послідовно сприяють реваскуляризації пошкодженої тканини за рахунок індукції міграції, проліферації, диференціювання та стабілізації ендотеліальних клітин у нових кровоносних судинах; відновлення пошкодженої сполучної тканини шляхом міграції, проліферації та активації фібробластів; та її проліферацію та диференціювання мезенхімальних стовбурових клітин на клітинні типи клітин. 3 цих причин плазма, збагачена тромбоцитами, використовується в регенеративній медицині для лікування декількох клінічних станів, включно виразки, опіки, кісткові захворювання та відновлення тканин після операції $[6,7]$.

Вищевказані процеси будуть змінюватись на тлі корекції збагаченої тромбоцитами плазми. Однак ці механізми потребують уточнення та додат- 
кового вивчення. Таким чином, плазма збагачена тромбоцитами, набула великої актуальності в останнє десятиліття, спрямованість експериментальних та клінічних досліджень в контексті загоєння ран та регенерації тканин $[8,9]$. Проте вплив ін'єкцій плазми (PRP) на загоєння м'язів ще недостатньо вивчений та $€$ актуальним.

Матеріали і методи. Експериментальне дослідження виконано на 92 нелінійних білих щурах масою 180-210 г, яких утримували на стандартному раціоні віварію. Тварин розділено на 3 групи: контроль - 12 щурів - інтактні, перша дослідна група з травматичним ураженням м'язів стегна без введення PRP (40 щурів), друга дослідна група - $з$ травматичним ураженням м'язів стегна та введенням PRP (40 щурів). Оскільки частина тварин у ході експерименту загинула, їх кількість у групах на момент евтаназії була різна.

Травму моделювали за розробленою методикою в умовах тіопентало-натрієвого знеболення (40 мг/кг) згідно з конвенцією [10,11]. Тварин на 1, 7, 14, 21 доби посттравматичного періоду виводили з експерименту. У крові визначали концентрацію ТБК-активних продуктів, яку вимірювали за допомогою кольорової реакції малонового діальдегіду (МДА) з тіобарбітуровою кислотою [12] та активність каталази [13] і оцінювали антиоксидантно/прооксидантний індекс АПІ, який свідчить про стан антиоксидантних і прооксидантних систем [14]. Також визначали рівень дієнових кон'югат за встановленою методикою [15].

PRP отримували методом двохетапного центрифугування, яке розпочинали шляхом пускання крові з серця білих щурів, у пробірку із антикоагулянтом у співвідношенні кров : антикоагулянт - $9: 1$ та поміщали у лабораторну центрифугу LMC-3000 “Biosan” (Латвія). Перше центрифугування проводили протягом 10 хвилин для осадження еритроцитів та лейкоцитів зі швидкістю 1600 об./хв. Після першого центрифугування плазму відокремлювали від концентрату еритроцитів. Друге центрифугування було проведене зі швидкістю 2100 об./хв протягом 10 хвилин. Отримана ЗТП містить тромбоцити в концентрації, що в 5 разів перевищує їх концентрацію в крові.

Матеріал для гістологічного дослідження отримували на 1-шу, 7-му, 14-ту і 21-шу доби після початку експерименту. Для здійснення гістологічного дослідження матеріал фіксували в $10 \%$ розчині забуференого нейтрального формаліну. Наступне проведення гістологічних препаратів здійснювалося згідно з загальноприйнятими методиками [16]. Фарбування препаратів здійсню- валося гематоксиліном та еозином, за якими вивчали структуру паренхіматозних органів у нормі, а також характер морфологічних змін після травми [16]. Для фотодокументації зображення з гістологічних препаратів виводили на монітор комп’ютера за допомогою мікроскопа Nicon eclipse C та цифрової відеокамери (Digital Camera SCMOS) за допомогою програмного забезпечення ToupWiev при різних збільшеннях.

Робота була проведена на базі кафедри патологічної фізіології, патологічної анатомії з секційним курсом та судовою медициною центральної науково-дослідної лабораторії (свідоцтво про атестацію № 001/18 від 26 вересня 2018 року) та міжкафедральної навчально-дослідної лабораторії (свідоцтво про атестацію №132/17 видане 29 грудня 2017 року) Тернопільського національного медичного університету імені І. Я. Горбачевського МОЗ України.

У роботі з тваринами дотримувались правил поводження 3 експериментальними тваринами згідно з директивою Ради ЄC 2010/63/EU про дотримання постанов, законів, адміністративних положень Держав ЄС з питань захисту тварин, які використовуються для наукової мети $[10,11]$.

Статистичну обробку результатів досліджень проводили за допомогою комп'ютерної програми Excel з використанням t-критерію Стьюдента.

Результати досліджень та їх обговорення. Згідно $з$ проведеними попередніми дослідженнями, ми встановили, що внаслідок травматичного ушкодження м'язів стегна гіперактивація процесів ліпідної пероксидації спостерігається вже на 1-шу добу, зростаючи до 7-ї доби посттравматичного періоду порівняно з тваринами без змодельованої патології.

Вивчення динаміки прооксидантно/антиокситдантного статусу в посттравматичному періоді представлені в таблиці 1. Згідно з представленими даними, в посттравматичному періоді показник ДК зростає на 1-шу добу у 3,2 раза, на 7-му - у 4,4 раза, 14-ту - 4,1 раза та на 21-шу добу - у 3,3 раза порівняно з інтактними тваринами. Концентрація проміжного продукту ліпідної пероксидації - МДА на 1-шу добу зросла у 2,2 раза, 7-му у 2,4 раза, 14-ту - у 1,7 раза та на 21-шу добу - в 1,6 раза порівняно з тваринами, яким моделювання травми не проводили.

За умов експериментальної корекції з використанням PRP відбувається пригнічення активності вільнорадикальних процесів, що веде до зниження рівня продуктів ПОЛ. Показник ДК на 1-шу добу спостереження суттєво не відрізнявся від аналогіч- 
ного показника тварин, яким корекцію не проводили, проте на 7-му добу склав 47,0 \% від показника тварин без корекції, на 14-ту - 32,9 \%, а на 21-шу - 31,8 \%, достовірно не перевищуючи рівень тварин без змодельованої патології (105,1%). Концентрація МДА у тварин, яким проводили корекцію, також знижувалась, проте дещо менше, ніж рівень
ДК: на 1-шу добу це зниження було не достовірним, однак на 7-му показник склав 79,9 \%. 14-ту 90,7 \%, 21-шу - 76,3 \% від рівня тварин, яким корекції не проводили. Варто зазначити, що до 21-ї доби показник МДА все ж був достовірно вищим, ніж у тварин, яким моделювання травми не проводили і склав 124,9 \% (табл. 1).

Таблиця 1. Показники прооксидантно/антиоксидантного статусу у тварин із травматичним ураженням

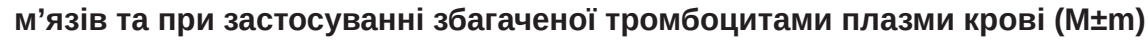

\begin{tabular}{|c|c|c|c|c|c|}
\hline \multirow{2}{*}{\multicolumn{2}{|c|}{ Група }} & \multicolumn{4}{|c|}{ Показник } \\
\hline & & ДК & МДА & каталаза, мкат/л & АПІ \\
\hline \multicolumn{2}{|c|}{ Інтактні $(n=12)$} & $0,97 \pm 0,01$ & $3,14 \pm 0,01$ & $4,77 \pm 0,01$ & 1,52 \\
\hline \multirow{4}{*}{$\begin{array}{l}\text { Перша група } \\
\text { (травма без } \\
\text { PRP) }\end{array}$} & 1-ша доба, (n=9) & $3,12 \pm 0,02 *$ & $7,02 \pm 0,02 *$ & $8,70 \pm 0,02 *$ & 1,23 \\
\hline & 7-ма доба, (n=8) & $4,32 \pm 0,02 *$ & $7,64 \pm 0,01^{*}$ & $7,96 \pm 0,02 *$ & 1,04 \\
\hline & 14-та доба, (n=8) & $4,01 \pm 0,02 *$ & $5,63 \pm 0,04^{*}$ & $5,68 \pm 0,02 *$ & 1,01 \\
\hline & 21-ша доба, (n=7) & $3,21 \pm 0,02 *$ & $5,14 \pm 0,04^{*}$ & $4,87 \pm 0,02 *$ & 0,94 \\
\hline \multirow{4}{*}{$\begin{array}{l}\text { Друга група } \\
\text { (травма } 3 \\
\text { PRP) }\end{array}$} & 1-ша доба, (n=9) & $3,09 \pm 0,02 *$ & $6,91 \pm 0,02 *$ & $9,82 \pm 0,02 *$ & 1,42 \\
\hline & 7-ма доба, (n=9) & $2,03 \pm 0,02 *$ & $6,11 \pm 0,02 *$ & $7,41 \pm 0,02 *$ & 1,21 \\
\hline & 14-та доба, (n=8) & $1,32 \pm 0,01 *$ & $5,11 \pm 0,03 *$ & $5,90 \pm 0,02 *$ & 1,16 \\
\hline & 21-ша доба, (n=8) & $1,02 \pm 0,01 *$ & $3,92 \pm 0,03 *$ & $4,94 \pm 0,02 *$ & 1,26 \\
\hline
\end{tabular}

Примітка: * - величини, які статистично достовірні від аналогічних показників у контрольній групі тварин (р < 0,05).

Результати нашого попереднього дослідження показали, що за умови корекції PRP відбувається значне зростання активності ферментів антиоксидантної системи, але більшість з них не досягає рівня показників контрольної групи. Більше того, уведення PRP спричинило підвищення рівня активності каталази на першу добу. На нашу думку, корекція м’язової травми збагаченою тромбоцитами плазмою на першу добу посттравматичного періоду супроводжувалась зменшенням оксидативного ушкодження міоцитів.

Показник АПІ, який вказує на наявний баланс прооксидантних і антиоксидантних механізмів, не нормалізувався у групах піддослідних тварин до кінця часу проведення експерименту. Такі результати вказують на те, що травматичне ураження м'язів викликає тривалі системні зміни та дисбаланс адаптаційно-компенсаторних механізмів, спрямованих на ліквідацію патологічних чинників.

Аналіз динаміки змін показника АПІ показав (рис. 1), що у групі тварин із м’язовою травмою, яким корекцію не проводили, на 1-шу добу він був меншим на 19,1 \%, на 7-му добу - на 31,6 \% $(\mathrm{p}<0,05)$, на 14-ту добу - на 33,6 \% $(\mathrm{p}<0,05)$ та на 21-шу - на 38,2 \% (p<0,05) порівняно з тваринами без змодельованої патології. У групі тварин, яким проводили корекцію з використанням PRP, показник АПІ на 1-шу добу зріс на 15,4 \% ( $<0,05)$, на 7-му добу - на 16,3 \% (p<0,05), 14-ту - на 14,9 \% а на 21-шу - на 34,0 \% порівняно з травмованими тваринами, яким корекцію не проводили.

У першій групі АПІ, який вказує на баланс прооксидантних та антиоксидантних механізмів, не нормалізувався до кінця експерименту.

У другій групі збагачена тромбоцитами плазма крові зменшує оксидативний стрес і має тенденцію до нормалізації співвідношення між оксидантною та прооксидантною системами.

При моделюванні травми на 7-му добу в ділянці пошкодження було виявлено м'язові волокна із ділянками деструкції у вигляді безструктурних мас, контрактури. Ядра слабо візуалізувались або були відсутніми. Поміж волокнами зустрічались поодинокі клітини фібробластичного ряду та макрофаги (рис. 2).

Однак на 7-й день у другій експериментальній групі із застосуванням PRP у пошкодженій ділянці, значна частина волокон збереглася, про що свідчить наявність ядер. Однак їх місце розташу- 


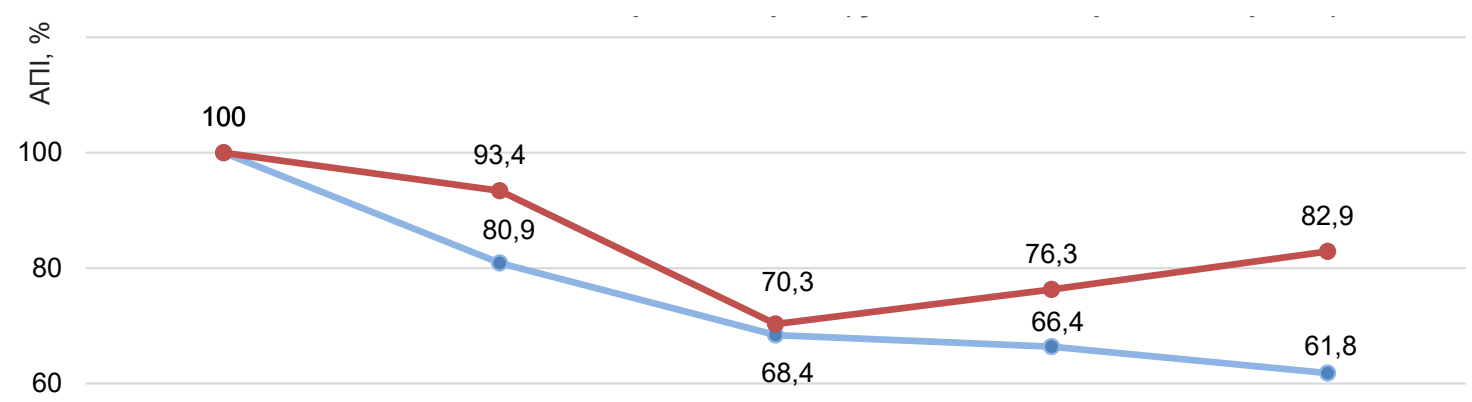

40

20

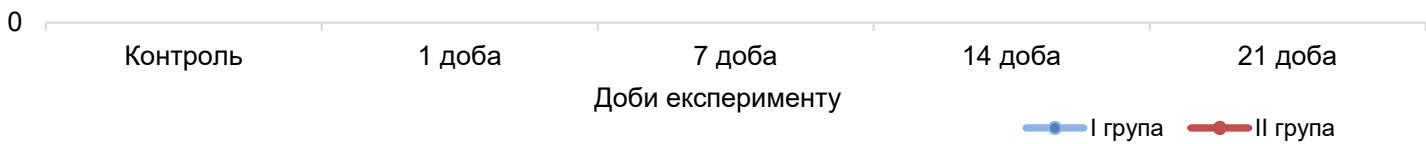

Рис. 1. Динаміка показника АПІ в сироватці крові (у відсотках від рівня контролю).

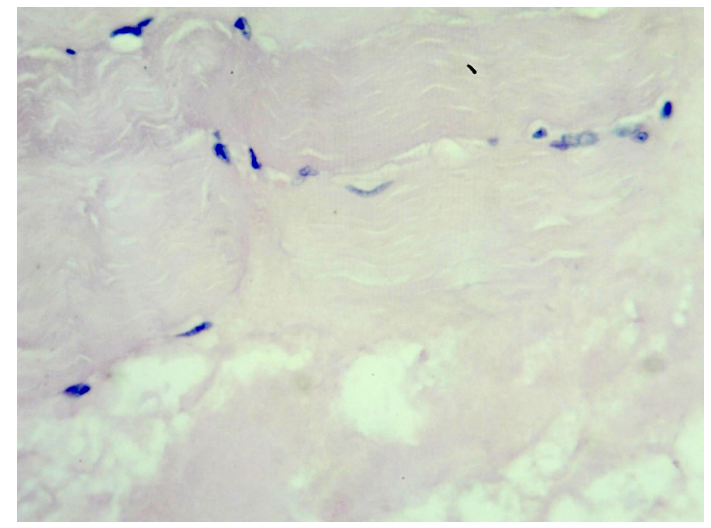

Рис. 2. Структура м’язів тварини в ділянці пошкодження на 7-му добу травми без корекції PRP. Забарвлення гематоксиліном та еозином. × 200.

вання було дещо змінено. Поряд з цим у досліджуваних структурах помірно спостерігалися дистрофічні зміни. Волокна оточені значною частиною колагену з ознаками набряку (рис. 3).

При моделюванні травматичного ураження м’язів на 14-ту добу в ділянці пошкодження візуалізувалась добре сформована колагенова строма 3 вираженим набряком, насичена клітинами як фібробластичного ряду, так і лімфоцитами та плазмоцитами. В м'язових волокнах спостерігались прояви білкової дистрофії, проте некротичні зміни не візуалізувались (рис. 4). Інтенсивність сприйняття барвників зростала.

При моделюванні травматичного ураження м’язів на 14-ту добу та проведення корекції PRP у ділянці пошкодження візуалізувалось зменшен-

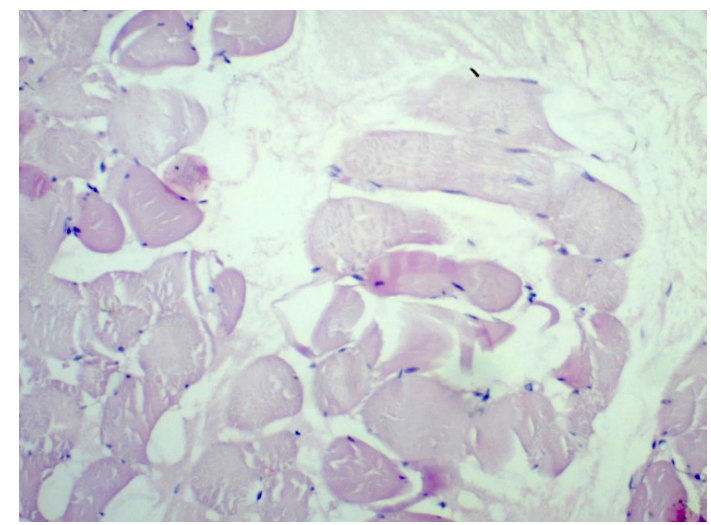

Рис. 3. М'язи тварини в ділянці пошкодження на 7-му добу після травми та корекції PRP. Забарвлення гематоксиліном та еозином. × 200 .

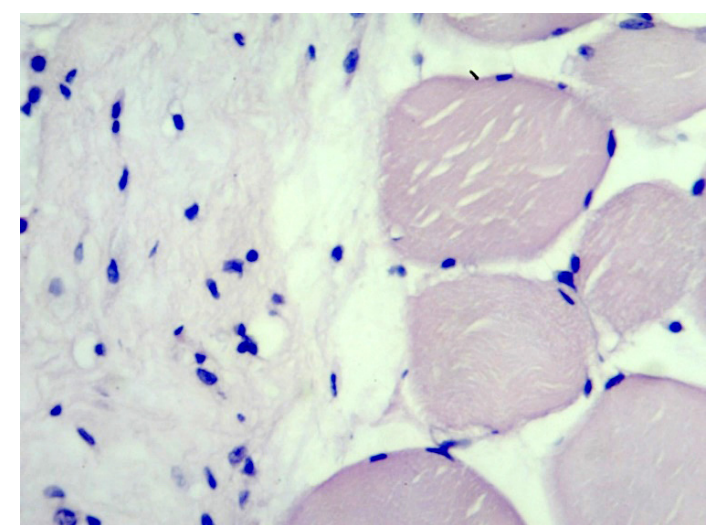

Рис. 4. М'язи тварини в ділянці пошкодження на 14-ту добу після травматичного ураження м’язів без корекції PRP. Забарвлення гематоксиліном та еозином. × 200. Колагенова строма з вираженим набряком. 
ня площі колагенової строми, виражене зменшення набряку, незначної кількості клітин фібробластичного ряду та формування нових судин мікроциркуляторного русла. В м’язових волокнах спостерігались прояви білкової дистрофії, проте некротичні зміни не візуалізувались (рис. 5).

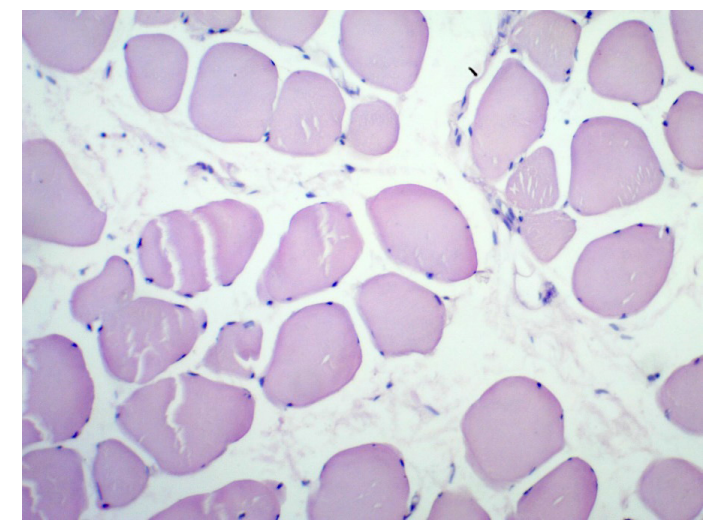

Рис. 5. М'язи тварини в ділянці пошкодження на 14-ту добу після травматичного ураження м'язів та корекції PRP. Забарвлення гематоксиліном та еозином. $\times 200$.

При моделюванні травматичного ураження м’язів на 21-шу добу в ділянці пошкодження у першій дослідній групі візуалізувалось зменшення площі загальної клітинної інфільтрації, формування капілярної сітки в ділянці грануляцій, дрібновогнищева перивакулярна лімфо-плазмоцитарна інфільтрація. Візуально зменшувалась кількість фібробластів та опасистих клітин. Проте помірний вогнищевий периваскулярний набряк переважав у ділянках проекції м’язових волокон. Інтенсивність сприйняття саркоплазмою барвників не зростала (рис. 6).

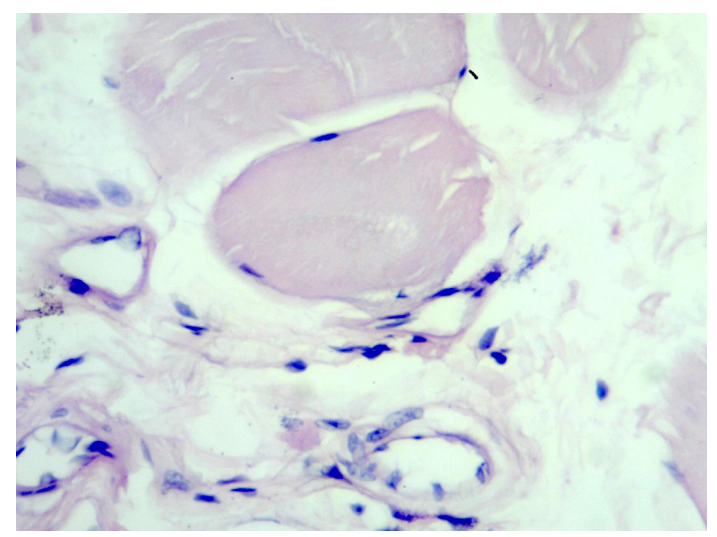

Рис. 6. М’язи тварини в ділянці пошкодження на 21-шу добу травматичного ураження м'язів без корекції PRP. Формування капілярної сітки, збільшення клітин фібробластичного ряду. Забарвлення гематоксиліном та еозином. $\times 200$.
При моделюванні травматичного ураження м’язів на 21-у добу з корекцією PRP в ділянці пошкодження пухкі колагенові волокна заміщувались гіалінізованою стромою. Різко зменшувалась кількість лімфо- та плазмоцитів, фібробластів, опасистих клітин та практично зникав периваскулярний набряк. Чітко збереженими візуалізувались судини мікроциркуляторного русла. Покращувалась структура власне м’язових волокон: саркоплазма інтенсивніше сприймала барвники, ядра відновлювали свою локалізацію (рис. 7).

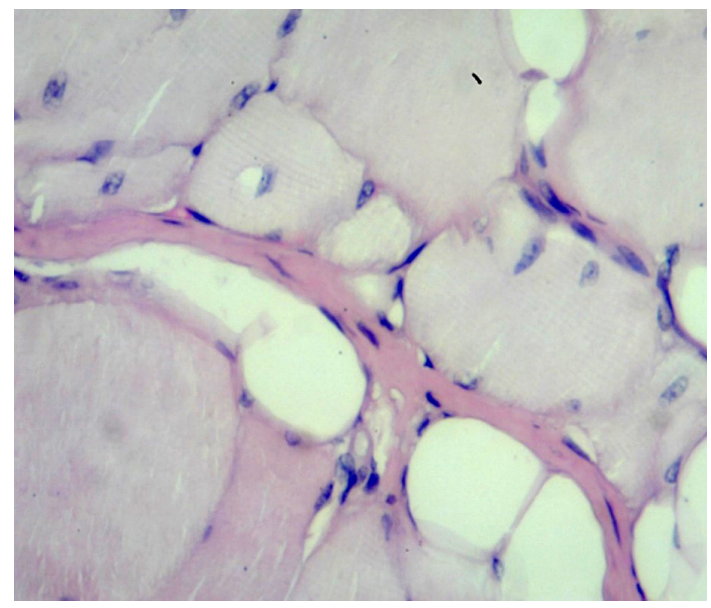

a

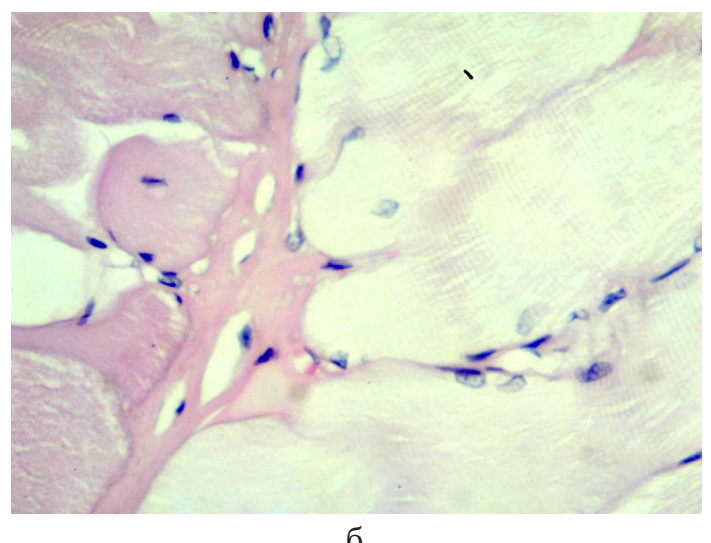

Рис. 7. М'язи тварини в ділянці пошкодження на 21-шу добу травматичного ураження м'язів при корекції PRP: а) відновлення структури м'язових волокон, ущільнення колагенових волокон, відсутність набряку; б) добре візуалізується поперечна посмугованість м'язових структур. Забарвлення гематоксиліном та еозином. $\times 200$.

Висновки. 1. Результати свідчать про розвиток значного дисбалансу прооксидантних і антиоксидантних механізмів, про що свідчить динаміка антиоксидантно-прооксидантного індексу, який до 21-ї доби спостереження знижувався у першій групі, а в другій групі, де призначали PRP, 
він зростав порівняно з першою групою та наближався до контролю.

2. Встановлено, що застосування збагаченої тромбоцитами плазми крові приводить до зменшення активності пероксидного окиснення ліпідів, що зумовлює зменшення ознак запалення в травмованому м'язі, які морфологічно проявляються на 7-му, 14-ту, 21-шу доби наступними змінами: на 7-му добу ділянка пошкодження була представлена помірними дистрофічними змінами в м'язових волокнах, незначним набряком та збільшенням кількості фібробластів. На 14-ту добу візуалізувалась незначна кількість

\section{СПИСОК ЛІТЕРАТУРИ}

1. Influence of PRP on morphological changes in muscle in the early period after traumatic muscle injury in the experiment / V. Dzhyvak, I. Klishch, T. Datsko, O. Khlibovska // Journal of Education, Health and Sport. - 2020. - Vol. 10 (6). - P. 171-178. eISSN 23918306. DOI http://dx.doi.org/10.12775/JEHS.2020.10.06.019.

2. Trends in 1029 trauma deaths at a level 1 trauma center / B. T. Oyeniyi, E. E. Fox, M. Scerbo [et al.] // Injury. - 2017. Vol. 48 (1). - P. 5-12.

3. Ніканоров О. К. Проблема травматизму в ігрових видах спорту та перспективи використання засобів фізичної реабілітації / О. К. Ніканоров // Спортивна медицина. - 2015. - № 1-2. - C. 82-86.

4. Hallen A. Return to play following muscle injuries in professional footballers / A. Hallen, J. Ekstrand // J Sports Sci. - 2014. - Vol. 32 (13). - P. 1229-36.

5. Kozakowska Magdalena. The role of oxidative stress in skeletal muscle injury and regeneration: focus on antioxidant enzymes / Magdalena Kozakowska, Katarzyna Pietraszek-Gremplewicz, Alicja Jozkowicz, Jozef Dulak // J. Muscle Res. Cell Motil. 2015. - Vol. 36. - P. 377-393. DOI 10.1007/s10974-015-9438-9. 6. Platelet-rich plasma reduces the oxidative damage determined by a skeletal muscle contusion in rats / Rodrigo Pereira Martins, Diane Duarte Hartmann, Jefferson Potiguara de Moraes [et al.] // Platelets. - 2016. - Vol. 27.

7. Geremicca Walter Blood components for topical use in tissue regeneration: evaluation of corneal lesions treated with platelet lysate and considerations on repair mechanisms / Walter Geremicca, Carla Fonte, Sisto Vecchio // Blood Transfus. - Vol. 8 (2). - P. 107-112.

8. Histologic evidence of new collagen formulation using platelet rich plasma in skin rejuvenation: A Prospective Controlled

\section{REFERENCES}

1. Dzhyvak, V., Klishch, I., Datsko, T., \& Khlibovska, O. (2020). Influence of PRP on morphological changes in muscle in the early period after traumatic muscle injury in the experiment. Journal of Education, Health and Sport, 10 (6), 171-178. eISSN 2391-8306. DOI: http://dx.doi.org/10.12775/JEHS.2020.10.06.019.

2. Blessing,T.O., Erin, E.F., Scerbo, M., Tomasek, J.S., Wade, C.E., \& Holcomb, J.B. (2017). Trends in 1029 trauma deaths at a level 1 trauma center. Injury, 48 (1), 5-12.

3. Nikanorov, O.K. (2015). Problema travmatyzmu v ihrovykh vydakh sportu ta perspektyvy vykorystannia zasobiv fizychnoi reabilitatsii [The problem of injuries in game sports and prospects колагенової строми із сформованою грануляційною тканиною, залишкові явища набряку та поодинокі дистрофічні зміни м'язів. Некротичні прояви не спостерігались. На 21-шу добу пухкі колагенові волокна заміщувались гіалінізованою стромою. Різко зменшувалась кількість лімфо- та плазмоцитів, фібробластів, опасистих клітин та практично зникав периваскулярний набряк. Чітко збереженими візуалізувались судини мікроциркуляторного русла. Покращувалась структура м'язових волокон: саркоплазма інтенсивніше сприймала барвники, ядра відновлювали свою локалізацію.

Clinical Study / Ozlem Karabudak Abuaf, Hamza Yildiz, Hüseyin Baloglu [et al.] // Ann. Dermatol. - 2016. - Vol. 28 (6). - P. 718724. - Access mode : https://doi.org/10.5021/ad.2016.28.6.718. 9. Cho J. W. Platelet-rich plasma induces increased expression of G1 cell cycle regulators, type I collagen, and matrix metalloproteinase-1 in human skin fibroblasts / J. W. Cho, S. A. Kim, K. S. Lee // Int. J. Mol. Med. - 2012. - Vol. 29. - P. 32-36.

10. Directive 2010/63/EU of the European Parliament and of the Council of 22 September 2010 on the protection of animals used for scientific purposes // Official Journal of the European Union. - 2010. - L276. - P. 33-79.

11. Guide for the care and use of laboratory animals. - 8th ed. Washington : The National Academies Press, 2011. - 246 p.

12. Стальная И. Д. Метод определения малонового диальдегида с помощью тиобарбитуровой кислоты / И. Д. Стальная, Т. Г. Гаришвили / / Современные методы в биохимии. - М. : Медицина, 1997. - С. 66-68.

13. Метод определения активности каталазы / М. А. Королюк, Л. И. Иванова, И. Г. Майорова, В. Е. Токарев // Лабораторное дело. - 1988. - № 1. - С. 16-19.

14. Антиоксидантно-прооксидантний індекс сироватки крові щурів з експериментальним стоматитом і його корекція зубними еліксирами / А. П. Левицький, В. М. Почтар, О.А. Макаренко, Л. І. Гридіна // Одеський мед. журн. - 2006. - № 1. C. 22-25.

15. Стальная И. Д. Метод определения диеновых конъюгат высших жирных кислот // Современные методы в биохимии / Под ред. В. Н. Ореховича. - М. : Медицина, 1977. - С. 63-64. 16. Методики морфологічних досліджень: монографія / Багрій М. М., Діброва В. А., Попадинець О. Г., Грищук І. М. ; за ред. М. М. Багрія, В. А. Діброви. - Вінниця : Нова книга, 2016. - 238 с.

for the use of physical rehabilitation]. Sportyvna medytsyna Sports Medicine, 1-2, 82-86 [in Ukrainian].

4. Hallen, A., \& Ekstrand J. (2014). Return to play following muscle injuries in professional footballers. J. Sports Sc., 32 (13), 1229-1236.

5. Magdalena Kozakowska, Katarzyna Pietraszek-Gremplewicz, Alicja Jozkowicz, \& Jozef Dulak (2015). The role of oxidative stress in skeletal muscle injury and regeneration: focus on antioxidant enzymes. J Muscle Res. Cell Motil., 36, 377-393. DOI 10.1007/s10974-015-9438-9.

6. Rodrigo Pereira Martins, Diane Duarte Hartmann, Jefferson Po- 
tiguara de Moraes, Felix Alexandre Antunes Soares \& Gustavo Orione Puntel (2016). Platelet-rich plasma reduces the oxidative damage determined by a skeletal muscle contusion in rats. Platelets, 27 7. Walter Geremicca, Carla Fonte, \& Sisto Vecchio (2010). Blood components for topical use in tissue regeneration: evaluation of corneal lesions treated with platelet lysate and considerations on repair mechanisms. Blood Transfus, 8 (2), 107-112.

8. Ozlem Karabudak Abuaf, Hamza Yildiz, Hüseyin Baloglu, Memet Ersan Bilgili, Hasan Aktug Simsek, \& Bilal Dogan (2016). Histologic evidence of new collagen formulation using platelet rich plasma in skin rejuvenation: A Prospective Controlled Clinical Study. Ann. Dermatol., 28 (6), 718-724. Retrieved from: https://doi.org/10.5021/ad.2016.28.6.718.

9. Cho, J.W., Kim, S.A,\& Lee, K.S. (2012).Platelet-rich plasma induces increased expression of G1 cell cycle regulators, type I collagen, and matrix metalloproteinase-1 in human skin fibroblasts. Int. J. Mol. Med., 29, 32-36.

10. Directive 2010/63/EU of the European Parliament and of the Council of 22 September 2010 on the protection of animals used for scientific purposes. Official Journal of the European Union, 2010, L276, 33-79.

11. (2011). Guide for the care and use of laboratory animals. 8th ed. Washington: The National Academies Press.

Електронна адреса для листування: djyvak@tdmu.edu.ua
12. Stalnaya, I. D. \& Garishvili, T.G. (1997). Metod opredeleniya malonovogo dialdegida s pomoshchyu tiobarbiturovoy kisloty [Method of determination of malonic dialdehyde with the help of thiobarbituric acid]. Moscow: Meditsina [in Russian].

13. Korolyuk, M.A., Ivanova, L.I., Mayorova, I.G., \& Tokarev, V.E. (1988). Metod opredeleniya aktivnosti katalazy [Method of determining catalase activity]. Laboratornoe delo - Laboratory Work, 1, 16-19 [in Russian].

14. Levitsky, A.P., Pochtar, V.M., Makarenko, O.A., \& Gridina L.I. (2006). Antyoksydantno-prooksydantnyi indeks syrovatky krovi shchuriv z eksperymentalnym stomatytom i yoho korektsiia zubnymy eliksyramy [Antioxidant-prooxidant index of serum of rats with experimental stomatitis and its correction with dental elixirs]. Odeskyi medychnyi zhurnal - Odesa Medical Journal, 1, 22-25 [in Ukrainian].

15. Stalnaya, I.D. (1977). Metod opredeleniya dienovyih konyugat vysshih zhirnykh kislot. [Method for determining diene conjugates of higher fatty acids] Orekhovich, V.N. (Ed.). Sovremennye metody v biokhymii - Modern Method in Biochemistry. Moscow: Meditsina [in Russian].

16. Bagriy, M., Dibrova ,V., Popadinets, O., \& Grishchuk, I. (2016). Metodyky morfolohichnykh doslidzhen [Methods of morphological researches]. Vinnytsia: Nova Knyha [in Ukrainian].

Отримано 22.05.2020

\author{
V. H. DZHYVAK, I. M. KLISHCH
}

I. Horbachevsky Ternopil National Medical University

\title{
EFFICACY OF PLATELET-RICH BLOOD PLASMA IN INDUCTION OF MUSCLE TISSUE HEALING IN AN EXPERIMENTAL STUDY
}

The aim of the work: to evaluate the effectiveness of platelet-rich blood plasma in the induction of muscle healing in an experimental study.

Materials and Methods. The experiment was performed on 92 laboratory rats, which were on the standard diet of the vivarium. Experimental animals were divided into three groups: control -12 intact, the first experimental group -40 with traumatic thigh muscle injury without the introduction of platelet-rich blood plasma, the second experimental group - 40 with traumatic thigh muscle injury and the introduction of platelet-rich blood plasma. Preparation of PRP took place in two stages. The effect of platelet-rich blood plasma correction on changes in lipid peroxidation (LPO) and antioxidant protection (AOC) and morphological changes in muscle tissue was analyzed in an experiment in traumatic muscle injury with platelet-rich blood plasma. Biological material was collected on the 1st, 7th, 14th, 21th day after traumatic muscle injury.

Results and Discussion It was found that the use of platelet-rich blood plasma reduces the activity of lipid peroxidation, which reduces the signs of inflammation in the injured muscle, which are morphologically manifested on the 7th, 14th day by the following changes: on the 7th day the area of damage was represented by moderate dystrophic changes in muscle fibers, slight edema and an increase in the number of fibroblasts. After 14 days, a small amount of collagen stroma with formed granulation tissue, residual edema and isolated dystrophic muscle changes were visualized, necrotic manifestations were not observed. On day 21, loose collagen fibers were replaced with a hyaline stroma at the site of injury. The number of lympho- and plasma cells, fibroblasts, mast cells decreased sharply and perivascular edema practically disappeared. The vessels of the microcirculatory tract were clearly visualized. The structure of the muscle fibers themselves improved: the sarcoplasm received dyes more intensively, the nuclei regained their localization.

Key words: muscle injury; platelet-rich blood plasma; PRP; lipid peroxidation; antioxidant system. 


\section{ЭФФЕКТИВНОСТЬ ОБОГАШЕННОЙ ТРОМБОЦИТАМИ П.ЛАЗМЫ КРОВИ В ИНДУКЦИИ ЗАКИВ.ЛЕНИЯ МЫШЕЧНОЙ ТКАНИ В ЭКСПЕРИМЕНТАЛЬНОМ ИСС.ЕДОВАНИИ}

Цель работы: оценить эффективность обогащенной тромбоцитами плазмы крови в индукции заживления мышечной ткани в экспериментальном исследовании.

Материалы и методы. Эксперимент проведен на 92 лабораторных крысах, которые находились на стандартном рационе вивария. Подопытные животные были разделены на три группы: контроль - 12 интактные, первая исследовательская группа - 40 с травматическим поражением мышц бедра без введения обогащенной тромбоцитами плазмы крови, вторая исследовательская группа - 40 с травматическим поражением мышц бедра и введением обогащенной тромбоцитами плазмы крови. Приготовление PRP происходило двухэтапного. Было проанализировано влияние коррекции обогащенной тромбоцитами плазмы крови на изменения пероксидного окисления липидов (ПОЛ) и антиоксидантной защиты (АОС) и морфологические изменения в мышечной ткани в эксперименте при травматическом поражении мышц, которым проводилась коррекция обогащенной тромбоцитами плазмой крови. Забор биологического материала проводили на 1-е, 7-е, 14-е, 21-е сутки после травматического поражения мышц.

Результаты исследований и их обсуждение. Установлено, что применение обогащенной тромбоцитами плазмы крови приводит к уменьшению активности пероксидного окисления липидов, что способствует уменьшению признаков воспаления в травмированной мышце, которые морфологически проявляются на 7-е, 14-е сутки, 21 сутки следующими изменениями: на 7-е сутки участок повреждения был представлен умеренными дистрофическими изменениями в мышечных волокнах, незначительным отеком и увеличением количества фибробластов. Через 14 суток визуализировалось незначительное количество коллагеновой стромы со сформированной грануляционной тканью, остаточные явления отека и единичные дистрофические изменения мышц, некротические проявления не наблюдались. На 21-е сутки в области повреждения рыхлые коллагеновые волокна замещались гиалинизированной стромой. Резко уменьшалось количество лимфо- и плазмоцитов, фибробластов, тучных клеток и практически исчезал периваскулярный отек. Четко сохраненными визуализировались сосуды микроциркуляторного русла. Улучшалась структура самих мышечных волокон: саркоплазма интенсивнее воспринимала красители, ядра восстанавливали свою локализацию.

Ключевые слова: травма мышц; обогащенная тромбоцитами плазма крови; PRP; пероксидное окисление липидов; антиоксидантная система. 